\title{
A conceptual model to retain non-professionals in a private healthcare setting
}

\begin{tabular}{|c|c|}
\hline \multicolumn{2}{|c|}{$\begin{array}{l}\text { Authors: } \\
\text { Shiksha Gallow }{ }^{1} \\
\text { Jo } \mathrm{Nel}^{2} \\
\text { Adri Williams }^{3}\end{array}$} \\
\hline \multicolumn{2}{|c|}{$\begin{array}{l}\text { Affiliations: } \\
{ }^{1} \text { Graduate School of Business } \\
\text { Leadership, University of } \\
\text { South Africa, Johannesburg, } \\
\text { South Africa }\end{array}$} \\
\hline \multicolumn{2}{|c|}{$\begin{array}{l}{ }^{2} \text { Department of English } \\
\text { Studies, University of } \\
\text { Limpopo, Polokwane, } \\
\text { South Africa }\end{array}$} \\
\hline \multicolumn{2}{|c|}{$\begin{array}{l}{ }^{3} \text { Edupark, Polokwane, } \\
\text { South Africa }\end{array}$} \\
\hline \multicolumn{2}{|c|}{$\begin{array}{l}\text { Corresponding author: } \\
\text { Shiksha Gallow, } \\
\text { shiksha@acasiasa.co.za }\end{array}$} \\
\hline \multicolumn{2}{|c|}{$\begin{array}{l}\text { Dates: } \\
\text { Received: } 27 \text { Sept. } 2019 \\
\text { Accepted: } 21 \text { Apr. } 2020 \\
\text { Published: } 07 \text { July } 2020\end{array}$} \\
\hline \multicolumn{2}{|c|}{$\begin{array}{l}\text { How to cite this article: } \\
\text { Gallow, S., Nel, J., \& } \\
\text { Williams, A. (2020). } \\
\text { A conceptual model to retain } \\
\text { non-professionals in a private } \\
\text { healthcare setting. SA Journal } \\
\text { of Human Resource } \\
\text { Management/SA Tydskrif vir } \\
\text { Menslikehulpbronbestuur, } \\
\text { 18(0), a1281. https://doi. } \\
\text { org/10.4102/sajhrm. } \\
\text { v18i0.1281 }\end{array}$} \\
\hline \multicolumn{2}{|c|}{$\begin{array}{l}\text { Copyright: } \\
\text { (C) } 2020 \text {. The Authors. } \\
\text { Licensee: AOSIS. This wor } \\
\text { is licensed under the } \\
\text { Creative Commons } \\
\text { Attribution License. }\end{array}$} \\
\hline \multicolumn{2}{|l|}{ Read online: } \\
\hline 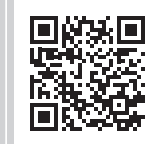 & $\begin{array}{l}\text { Scan this QR } \\
\text { code with your } \\
\text { smart phone or } \\
\text { mobile device } \\
\text { to read online. }\end{array}$ \\
\hline
\end{tabular}

Background: Non-professionals are carriers of institutional knowledge and are essential to the effective functioning of healthcare institutions. However, most studies on retention in the healthcare environment focus on professionals.

Objective: The aim of this study was to develop a conceptual model pertaining to the retention of non-professionals in the healthcare sector.

Methods: A total of 72 non-professional and, for the purpose of contract, 116 professional employees were surveyed. The independent variables were job characteristics, job satisfaction and career anchors. The dependent variables were organisational commitment and intention to quit. The analysis focused on the way the independent variables correlated with the dependent variables.

Results: It was possible to identify individual elements in the independent variables that relate to the dependent variables. It was thus possible to extrapolate and develop a conceptual model for the retention of non-professionals in the healthcare sector. The results also revealed that, for the professionals, the independent variables were less effective in predicting retention.

Conclusion: A retention strategy that focuses on the specific variables could be effective for the retention of non-professionals. Also, the independent variables used in this study do not predict retention in the professional group. It may thus be necessary to address retention for non-professionals and professionals in the healthcare sector differently.

Keywords: retention; conceptual model; pathology; job retention; career anchors.

\section{Introduction}

\section{Orientation}

There are obvious reasons why staff turnover in the healthcare environment should be minimised. Mazurenko, Gupte and Shan (2015) refer to important consequences: 'decreased patient access, patient safety and quality of care leading to adverse outcomes' of high staff turnover (p. 48). Most studies on retention in the healthcare environment focus on professionals (e.g. Geun, Redman, \& McCullagh, 2016; Hayward, Bungay, Wolff, \& MacDonald, 2016; Kaye \& Jordan-Evans, 2014; Yu \& Kang, 2016). This may have unintended and acute consequences, as the support staff - that is, the non-professionals - are carriers of institutional knowledge and are essential to the effective functioning of healthcare institutions (Encinares \& Pullan, 2003; Lin, Yu, \& Zhang, 2014; Vlastarakos \& Nikolopoulos, 2008). In this regard, selected previous research has shown that retention models for those on different staff levels differ (Staggs \& Dunton, 2012; Wheeler, Halbesleben, \& Harris, 2012).

Retention (in general) has been associated with many antecedents, for example, task, organisational, personality and demographic factors (Shahnawaz \& Jafri, 2009). Task factors, such as job characteristics (Chang, Wang, \& Huang, 2013), organisational factors, for example, role conflict (Tiplic, Brandmo, \& Elstad, 2015), opportunities for career advancement and procedural fairness (Shahzad, Hayat, Abbas, \& Bashir, 2011), as well as the work environment (Duffield, Roche, Blay, \& Stasa, 2011; Mi, 2016) and management leadership (Leveck \& Jones, 1996) are said to influence turnover. Factors such as locus of control, perceived organisational support, job satisfaction and organisational commitment (Chiu, Lin, Tsai, \& Hsiao, 2005), and demographic factors, such as age (Buengeler, Homan, \& Voelpel, 2016) and age coupled with tenure similarity amongst employees (Chang et al., 2013), have demonstrated an influence on retention. Retention has been associated with compensation and benefits (Jordan, 2009). 


\section{Research purposes and objectives}

Within the domain of healthcare, retention was specifically associated with affective professional commitment, job satisfaction, organisational commitment and intention to change professions (Parry, 2008). Barak, Nissly and Levin (2001) point to burnout, job dissatisfaction, availability of employment alternatives, low organisational and professional commitment, stress and lack of social support as strong predictors of turnover or intention to leave. Lack of career development and lack of training opportunities are also related to retention in the healthcare field (Chipeta, 2014). Jooste (2009) also states that healthcare professionals 'expect that their performance will correlate with the rewards received from the organisation' (p. 288). Furthermore, Race and Skees (2010) report that retention within the healthcare domain is associated with good mentoring as is preceptorship (Yonge, Myrick, Billay, \& Luhanga, 2007). In the past, job characteristics (Ghosh, Rai, Chauhan, Gupta, \& Singh, 2015; Uruthirapathy \& Grant, 2015), job satisfaction (Hudgins, 2016) and career anchors (Guan et al., 2014; Wen \& Liu, 2015) were also used in empirical research as antecedents to retention. The purpose of this study was to test the importance of job characteristics, job satisfaction and career anchors, in retaining non-professional in the private healthcare system.

\section{Literature review}

Job characteristics (Ghosh et al., 2015) and job satisfaction (Adegoke, Atiyaye, Abubakar, Auta, \& Aboda, 2015) are closely related to retention. Along similar lines, Schein's career anchors are often used as a predictor of retention (Msondo, 2014; Osuji, Uzoka, Aladi, \& El-Hussein, 2014). Equally, intention to quit (Lartey, Cummings, \& ProfettoMcGrath, 2014) and organisational commitment (Van Dyk \& Coetzee, 2012) are often seen as proxies to retention. Given the aforementioned, three antecedents to retention, namely, job characteristics, satisfaction and career anchors, were identified, as were two proxies to retention, namely, organisational commitment and intention to quit.

According to the job-characteristic theory, skill variety (the range of tasks performed), task identity (the ability to complete the whole job from start to finish) and task significance (the impact of the job on others) contribute to the meaningfulness of the work, while autonomy (the extent of discretion and freedom an employee has over his or her tasks) and feedback (the extent to which the job provides the employee with information about the effectiveness of his or her performance) contribute to the motivation of the employee (Hackman \& Oldham, 1975). Wall, Clegg and Jackson (1978), almost 40 years ago, found that job characteristics are related to intrinsic motivation, job performance, job satisfaction as well as absenteeism and the retention of employees. It could well be expected that those variables still influence a person's intention to remain in an organisation or be committed to it.

The elements of job satisfaction, as proposed by Hackman and Oldham (1975), namely, job, pay, security, social, supervisor and growth satisfaction, as often referenced in academic literature (Behson, 2010; Debacker, 2013), are seldom explained in greater detail, and also not explained in the original instrument development document (Hackman \& Oldham, 1974). However, it seems self-explanatory as is the link between satisfaction and turnover (Adegoke, 2014).

Schein (1975) identified eight career anchors. These are the following:

- technical/functional (referring to individuals motivated by doing what they are good at and aim to grow in expertise in an area)

- general managerial (referring to individuals who want to lead others and aspire to decision-making and motivating others)

- autonomy/independence (referring to individuals who need a feeling of autonomy and independence and seek to work alone or in a situation which they can control)

- security/stability (referring to individuals who try to avoid uncertainty and tend to seek stability in their workplace

- entrepreneurial creativity (referring to those who are motivated by creating something new and bring new perspectives ideas to the fore)

- service/dedication to a cause (referring to those who want to see themselves as being of value, to other people, helping people or to a cause, such as animal rights)

- pure ch1allenge (referring to individuals who are motivated by success, promotion and recognition, as well as competing against others)

- lifestyle (referring to those concerned with work-life balance and seeing work as a means for doing things they view as being of value).

From the aforementioned, it is evident that certain individuals would be attracted to certain work environments, while others would be repelled by a work environment that does not satisfy their needs. Career anchors are enduring and would not be relinquished, even if the employee is faced with difficult career choices (Gubler, Biemann, Tschopp, \& Grote, 2015).

From the above, the link between these variables seems straightforward and well researched. However, studying the references to the variables, particularly those who make reference to the medical profession, it is evident that attention is only given to professionals in the field (Alam \& Shahi, 2015; Warmelink, Wiegers, De Cock, Spelten, \& Hutton, 2015). None of the research reports listed here make any reference to support or administrative staff. The focus of this research was to assess whether all staff are cut from the same cloth, and if managers should treat all employees similarly, when the aim is to retain them.

\section{Research methods}

\section{Research design}

The research was an exploratory study making use of a crosssectional survey design. The aim was to assess the extent to which traditional antecedents to retention apply to non-professionals employed in the private healthcare environment. 


\section{Sampling}

The target population was all non-professional employees working in South Africa in the private healthcare domain. For the purpose of the study, privately owned pathology laboratories were targeted. A list of employees with all their information was acquired from the human resource department of the different laboratories. All employees (professional and non-professional) were invited to participate in the study.

\section{Ethical consideration}

Ethical approval for this study was granted by UNISA School of Business Leadership (UNISA SBL's) ethics committee. No ethical breaches occurred during the study.

\section{Research plan}

After gaining permission to conduct the research from the different managers of the laboratories, and getting ethical clearance for the university, all employees were approached to complete five questionnaires: three on antecedents to retention and two that acted as proxies to retention. Then, the data were captured and analysed to assess the level of overlap between the independent and the dependant variables. The results were used to develop a model for the retention of nonprofessional staff in the private healthcare environment.

In the analysis, a distinction was made between professional and non-professional staff. Those registered with statutory bodies such as the Health Professions Council of South Africa (HPCSA) or the South African Nursing Council (SANCA) were deemed to be professionals and the rest were considered to be non-professionals.

\section{Measuring instrument}

The Job Characteristic Scale forms part of the Job Diagnostic Survey (Hackman \& Oldham, 1975) and consists of five sections, namely, skill variety, task identity, task significance, autonomy and feedback. The Job Diagnostic Survey (Hackman \& Oldham, 1975) also contains a measure called the Job Satisfaction Scale, with sections called job, pay, security, social, supervisor and growth satisfaction. The Career Orientation Inventory (COI) was developed by Schein (1996) following De Long (1982). It measures eight career anchors, namely, technical/functional competence, general managerial competence, autonomy, security/stability, entrepreneurial creativity, service/ dedication to a cause, pure challenge as well as the career anchor lifestyle. The Organizational Commitment Scale (Allen \& Meyer, 1990) measures three-dimensional organisational commitment, focusing on affective, continuance and normative commitment. In this study, the focus will only be on the overall commitment score. The Intention to Quit Questionnaire, adopted from Arnold and Feldman (1982), measures the intention to quit with a unidimensional four-item scale.

All of these measures are well known in the organisational behaviour environment and display acceptable levels of reliability and validity and have been used in numerous studies.

\section{Statistical analysis and decision-making}

Statistical analysis focuses on correlations as well as on regression analysis. Correlations were calculated to identify which of the independent variables overlapped the most with the dependent variables. Statistically significant correlations $(p<0.01)$, with medium effect $(R \geq$ 0.30), as per Cohen (1988), will be deemed as practically significant and will be included in the conceptual model (i.e. retention strategy). Regression analysis will be used to identify how the group of variables (job characteristics, satisfaction and career anchors) together predict the dependent variables. $R^{2} \geq 0.20$ would be deemed as practically significant; Cohen (1988) states that when shared variance is greater than $20 \%$, it may be interpreted as practically meaningful.

\section{Findings}

In the section that follows, a description of the participants is provided as well as the results pertaining to the correlations between the constructs. The rest of the findings focus on the relationships between the independent (job characteristic, job satisfaction and career anchors) and dependent variables (organisational commitment and intention to quit).

\section{Description of the participants}

In total, 188 respondents answered the questionnaires. Amongst them, 53 (22.8\%) were male and 135 (71.8\%) were female. The respondents' ethnicity was as follows: $37.8 \%$ African, 23.9\% Caucasian, 20.7\% Asian and 17.6\% mixed race. In total, 116 professionals and 72 non-professionals employees were surveyed.

\section{Correlation between antecedents and proxies of retention}

In Table 1, the correlation between job characteristics and intention to quit and organisational commitment per staff status are presented.

From Table 1, it can be deduced that most job characteristics predict intention to quit in the non-professional group.

TABLE 1: Correlation between job characteristics and intention to quit and organisational commitment per staff status.

\begin{tabular}{lccccc}
\hline Job characteristics and ... & \multicolumn{2}{c}{ Intention to quit } & & Organisational commitment \\
\cline { 2 - 3 } \cline { 5 - 6 } $\begin{array}{c}\text { Non- } \\
\text { professional }\end{array}$ & Professional & & $\begin{array}{c}\text { Non- } \\
\text { professional }\end{array}$ & Professional \\
\hline Skill variety & $-0.320^{* *}$ & -0.002 & & -0.117 & 0.106 \\
Task identity & $0.289^{* *}$ & 0.113 & & 0.108 & 0.031 \\
Task significance & $-0.440^{* *}$ & -0.011 & & -0.181 & 0.099 \\
Autonomy & $-0.365^{* *}$ & -0.032 & & 0.093 & -0.132 \\
Feedback from job itself & $0.959^{* *}$ & 0.128 & & -0.043 & 0.098 \\
$R^{2}$ & 0.473 & 0.083 & & 0.168 & 0.077 \\
$R^{2}$-adjusted & 0.415 & 0.024 & & 0.111 & 0.053 \\
\hline
\end{tabular}

Note: Practically significant results are presented with shading.

Difference is significant at the .05 level (2-tailed)

$* *$, Difference is significant at the .01 level (2-tailed) 
This is also reflected in the regression coefficients, which is practically significant. Providing skill variety, task significance and autonomy will retain employees. Indeed, the feedback from the job itself seems to coincide with nonprofessional employees wanting to quit their jobs. Note that none of the job characteristics seem to create commitment to the organisation, amongst the non-professionals.

None of these traditional predictors of retention seem to be effective in the professional group. This also applies to organisational commitment.

In Table 2, results pertaining to career anchors and the proxies to retention are presented.

From Table 2, it can be inferred that an environment with high technical/functional competence, general managerial competence, security/stability and service/dedication to a cause retains employees (i.e. they do not want to quit). However, pure challenge seems to have a negative effect, causing employees to want to leave.

Even though none of the individual career anchors overlapped at a practical level with organisational commitment, the overall model, the regression model (see $R^{2}$ ), suggests that it does indeed contribute to commitment. Career anchor is, however, a much weaker predictor of organisational commitment than intention to quit.

As was the case with job characteristics, none of the career anchor variables overlapped in a practical and meaningful manner with the proxies to retention in the professional group. Career anchors thus predict intention to quit and organisational commitment amongst non-professionals, but fail to do that amongst the professionals in the healthcare system.

The results pertaining to satisfaction, on the one hand, and the proxies of retention, on the other hand, are presented in Table 3.

From Table 3, it is evident that high levels of pay, security, social and supervisory satisfaction contribute to employees not intending to quit the organisation. It is interesting to note

TABLE 2: Correlation between career anchors and intention to quit and organisational commitment per staff status.

\begin{tabular}{lccccc}
\hline Career anchors and ... & \multicolumn{2}{c}{ Intention to quit } & & Organisational commitment \\
\cline { 2 - 3 } \cline { 5 - 6 } $\begin{array}{c}\text { Non- } \\
\text { professional }\end{array}$ & Professional & & $\begin{array}{c}\text { Non- } \\
\text { professional }\end{array}$ & Professional \\
\hline Technical & $-0.627^{* *}$ & $-0.209 *$ & & 0.276 & -0.14 \\
Managerial & $-0.613^{* *}$ & $-0.264^{* *}$ & & $0.261 *$ & 0.060 \\
Autonomy & -0.077 & -0.182 & & 0.068 & 0.126 \\
Security & $-0.655^{* *}$ & -0.123 & & 0.052 & $0.195^{*}$ \\
Entrepreneur & -0.166 & -0.103 & & 0.173 & 0.139 \\
Service & $-0.741 * *$ & -0.031 & & $0.242 *$ & 0.021 \\
Challenge & $0.759 * *$ & $0.244 * *$ & & 0.215 & 0.012 \\
Lifestyle & -0.073 & $-0.232 *$ & & 0.021 & 0.117 \\
$R^{2}$ & 0.736 & 0.239 & & 0.448 & 0.062 \\
$R^{2}$-adjusted & 0.702 & 0.182 & & 0.378 & 0.002 \\
\hline
\end{tabular}

Note: Practically significant results are presented with shading.

*, Difference is significant at the .05 level (2-tailed); **, Difference is significant at the .01 level (2-tailed) that only the possibility of growth (growth satisfaction) contributes to commitment to the organisation. Not one of the other types of satisfaction, including pay satisfaction, contributed to commitment to the organisation.

As was the case with the other variables, no practically significant shared variance was found in the professional group. Job satisfaction is thus a poor predictor of proxies to retention amongst professionals in the healthcare system.

In Table 4, the results of the previous tables are combined to highlight where managers could focus their effort should the aim be to retain non-professional staff in the private healthcare sector.

As can be noted from Table 4, managers need to provide more inducements in the case of negative correlations and fewer in the case of positive correlations to retain nonprofessional staff.

TABLE 3: Correlation between satisfaction and intention to quit and organisational commitment per staff status.

\begin{tabular}{lccccc}
\hline Satisfaction and ... & \multicolumn{2}{c}{ Intention to quit } & & \multicolumn{2}{c}{ Organisational commitment } \\
\cline { 2 - 3 } \cline { 5 - 6 } & $\begin{array}{c}\text { Non- } \\
\text { professional }\end{array}$ & Professional & & $\begin{array}{c}\text { Non- } \\
\text { professional }\end{array}$ & Professional \\
\hline Job satisfaction & 0.207 & $-0.200 *$ & & 0.056 & 0.125 \\
Pay satisfaction & $-0.720 * *$ & 0.140 & & 0.127 & -0.086 \\
Security & $-0.406 * *$ & 0.025 & & 0.192 & -0.069 \\
Social satisfaction & $-0.768 * *$ & -0.028 & & 0.210 & -0.047 \\
Supervisory & $-0.683 * *$ & -0.012 & & 0.191 & -0.042 \\
Growth & -0.166 & 0.015 & & $0.556 * *$ & -0.083 \\
$R^{2}$ & 0.674 & 0.073 & & 0.332 & 0.022 \\
$R^{2}$-adjusted & 0.644 & 0.022 & & 0.271 & -0.032 \\
\hline
\end{tabular}

Note: Practically significant results are presented with shading.

$*$, Difference is significant at the .05 level (2-tailed); **, Difference is significant at the .01 level (2-tailed)

TABLE 4: Retention model for non-professional workers in the private healthcare environment.

\begin{tabular}{lcccc}
\hline Job characteristics and ... & $\begin{array}{c}\text { Intention to } \\
\text { quit }\end{array}$ & Provide ... & $\begin{array}{c}\text { Organisational } \\
\text { commitment }\end{array}$ & Provide ... \\
\hline Skill variety & $-0.320^{* *}$ & More & -0.117 & - \\
Task identity & $0.289^{* *}$ & - & 0.108 & - \\
Task significance & $-0.440^{* *}$ & More & -0.181 & - \\
Autonomy & $-0.365^{* *}$ & More & 0.093 & - \\
Feedback from job itself & $0.959^{* *}$ & Less & -0.043 & - \\
Career anchors and ... & & & & - \\
Technical & $-0.627 * *$ & More & 0.276 & - \\
Managerial & $-0.613^{* *}$ & More & $0.261^{*}$ & - \\
Autonomy & -0.077 & - & 0.068 & - \\
Security & $-0.655^{* *}$ & More & 0.052 & - \\
Entrepreneur & -0.166 & - & 0.173 & - \\
Service & $-0.741^{* *}$ & More & $0.242^{*}$ & - \\
Challenge & $0.759 * *$ & Less & 0.215 & - \\
Lifestyle & -0.073 & - & 0.021 & - \\
Satisfaction and ... & & & & - \\
Job satisfaction & 0.207 & - & 0.056 & - \\
Pay satisfaction & $-0.720^{* *}$ & More & 0.127 & - \\
Security & $-0.406^{* *}$ & More & 0.192 & - \\
Social satisfaction & $-0.768^{* *}$ & More & 0.210 & - \\
Supervisory & $-0.683^{* *}$ & More & 0.191 & - \\
Growth & -0.166 & - & $0.556^{* *}$ & More \\
\hline
\end{tabular}

Note: Practically significant results are presented with shading.

*, Difference is significant at the .05 level (2-tailed); **, Difference is significant at the .01 level (2-tailed) 


\section{Discussion}

From the analysis presented, it can be observed that job characteristics, satisfaction and career anchors overlap with intentions to quit. The values were $R^{2}=0.473,0.736$ and 0.674 , respectively. This suggests that meeting career anchor expectations could be the best strategy to prevent nonprofessional staff from quitting. It is also important to note that only job satisfaction contributes to organisational commitment, with opportunities for growth as the primary driver in this case.

It was possible to develop a retention strategy for nonprofessionals in the private healthcare sector. Managers are urged to focus on the elements highlighted in Table 4 when they strive to retain employees. Although it may be important to focus on certain aspects, managers also need to be aware of the factors that do not contribute to retention. It is recommended that with regard to job characteristics, improved skill variety, task significance and autonomy will contribute to reducing intentions to quit, while feedback from the job itself seems to promote intentions to quit. It thus seems that when considering job characteristics, it would be unwise to design jobs that automatically provide feedback, if retention is the aim. Considering the eight career anchors, five seem to influence the intention to quit. Improving conditions that will strengthen the technical, managerial, security and service career anchors will diminish the inclination to want to quit, while stimulating the challenge career anchor will have the opposite effect. While general satisfaction with the job does not affect intentions to quit amongst non-professionals, satisfaction regarding pay, security, supervision and social interactions does. Improving these conditions may curtail intentions to quit.

An important finding from this research is that not intending to quit does not equate to commitment to the organisation. It may be inferred from these results that the concepts may have different meanings to the respondents and it seems as if different antecedents influence the two variables.

Perhaps, the most striking finding of the research is the inability of the independent variables to predict the proxies to retention in the professional group. This was the case for all the predictors and on all the sub-scales. This suggests that traditional antecedents to retention fail as predictors for professionals in the private healthcare sector. The implication is that different strategies may be necessary for the retention of different categories of employees.

\section{Conclusion}

It has been noted from the existing literature that few retention strategies exist for public health workers, and more effective strategies are needed in South Africa. The findings for this article have been derived from valid and concise research methods, and provide empirically based evidence to this effect. As previously discussed, meeting career anchor expectations could be the best strategy to prevent non- professional staff from quitting. Alhassan and Poku (2018), Chipeta (2014), Jiang and Klein (1999), Lee and Park (2018), Muller, Bezuidenhout and Jooste (2009) and Weiss (2019) suggest that career-anchor-related interventions would influence retention. Managers are thus encouraged to focus on career anchor 'fulfilment' as the most effective strategy to retain non-professionals in the private healthcare system.

This study reinforces the idea that traditional retention strategies are suitable to retain non-professionals, and in addition highlights the importance of focussing on specific antecedents. It further accentuates the need to differentiate between retention strategies for professional and nonprofessionals. This is in line with the previous findings (see Staggs \& Dunton, 2012; Wheeler et al., 2012). The contribution of this study is providing a retention model using and contrasting several variables, namely, career anchors, job characteristics, job satisfaction, organisational commitment and intention to quit, in relation to the retention of non-professionals. A retention model for the healthcare non-professionals was developed. This model not only contributes to the body of knowledge, but is also a useful managerial tool to manage non-professionals (and professionals) in the health sector.

\section{Acknowledgements}

The authors thank UNISA School of Business Leadership (UNISA SBL) for the support provided to conduct the study.

\section{Competing interests}

The authors have declared that no competing interest exists.

\section{Authors' contributions}

S.G. was the main author, and the rest were co-authors.

\section{Funding information}

This research received no specific grant from any funding agency in the public, commercial or not-for-profit sectors.

\section{Data availability statement}

Data sharing is not applicable to this article as no new data were created or analysed in this study.

\section{Disclaimer}

The views and opinions expressed in this article are those of the authors and do not necessarily reflect the official policy or position of any affiliated agency of the authors.

\section{References}

Adegoke, A.A., Atiyaye, F.B., Abubakar, A.S., Auta, A. \& Aboda, A. (2015). Job satisfaction and retention of midwives in rural Nigeria. Midwifery, 31(10), 946-956. https://doi.org/10.1016/j.midw.2015.06.010

Adegoke, T.G. (2014). Effects of Occupational Stress on Psychological Well-being of Police Employees in Ibadan Metropolis, Nigeria. African Research Review 8(1), 19-25. 
Alam, T., \& Shahi, M. (2015). Factors affecting job satisfaction, motivation and turnover rate of medical promotion officer (MPO) in pharmaceutical industry: A turnover rate of medical promotion officer (MPO) in pharmaceutical industry: A study based in Khulna City.
org/10.18034/abr.v1i2.324

Alhassan, R.K., \& Poku, K.A. (2018). Experiences of frontline nursing staff on workplace safety and occupational health hazards in two psychiatric hospitals in Ghana. BMC Public Health, 18(1), 701. https://doi.org/10.1186/s12889-018-5620-5

Allen, N.J., \& Meyer, J.P. (1990). The measurement and antecedents of affective, continuance and normative commitment to the organization. Journal of Occupationa Psychology, 61, 1-18. https://doi.org/10.1111/j.2044-8325.1990.tb00506.x

Arnold, H., \& Feldman, D. (1982). A multivariate analysis of the determinants of job turnover. Journal of Applied Psychology, 67(3), 350-360. https://doi. org/10.1037/0021-9010.67.3.350

Barak, M.M., Nissly, J.A., \& Levin, A. (2001). Antecedents to retention and turnove among child welfare, social work, and other human service employees: What can we learn from past research? A review and meta-analysis. Social Service Review, 75(4), 625-661. https://doi.org/10.1086/323166

Behson, S.J. (2010). Using relative weights to reanalyze 'settled' areas of organizational behavior research: The job characteristics model and organizational justice. International Journal of Management and Information Systems, 14(5), 43-55. https://doi.org/10.19030/ijmis.v14i5.12

Buengeler, C., Homan, A.C., \& Voelpel, S.C. (2016). The challenge of being a young manager: The effects of contingent reward and participative leadership on teamlevel turnover depend on leader age. Journal of Organizational Behavior, 37(8), 1224-1245. https://doi.org/10.1002/job.2101

Chang, W.A., Wang, Y., \& Huang, T. (2013). Work design-related antecedents of turnover intention: A multilevel approach. Human Resource Management, 52(1) 1-26. https://doi.org/10.1002/hrm.21515

Chipeta, J. (2014). Factors that affect staff morale in tertiary hospitals in Malawi: A case study of Kamuzu Central Hospital. Journal of Human Resource and Sustainability Studies, 2(4), 230-238. https://doi.org/10.4236/jhrss.2014.24024

Chiu, C., Lin, C., Tsai, Y.H., \& Hsiao, C. (2005). Modeling turnover intentions and their antecedents using the locus of control as a moderator: A case of customer service employees. Human Resource Development Quarterly, 16(4), 481-499. https://doi. org/10.1002/hrdq.1152

Cohen, J. (1988). Statistical power analysis for the behavioural sciences (2nd edn.) Hillsdale, NJ: Lawrence Erlbaum Associates.

Debacker, J.P. (2013). Instructional coach job satisfaction: An exploration of role stressors. Doctoral dissertation, University of Kansas, Missouri Kansas.

De Long, T.J. (1982). Reexamining the career anchor model. Personnel, 59(3), 60-61.

Duffield, C.M., Roche, M.A., Blay, N., \& Stasa, H. (2011). Nursing unit managers, staff retention and the work environment. Journal of Clinical Nursing, 20(1-2), 23-33. https://doi.org/10.1111/j.1365-2702.2010.03478.x

Encinares, M., \& Pullan, S. (2003). The balancing act: Collaboration between frontline forensic staff and hospital administration. Journal of Psychosocial Nursing \& Mental Health Services, 41(12), 36-47.

Geun, H.G., Redman, R.W., \& McCullagh, M.C. (2016). Turnover and associated factors in Asian foreign-educated nurses. The Journal of Nursing Administration, 46(5) 271-277. https://doi.org/10.1097/NNA.0000000000000342

Ghosh, P., Rai, A., Chauhan, R., Gupta, N., \& Singh, A. (2015). Exploring the moderating role of context satisfaction between job characteristics and turnover intention of employees of Indian public sector banks. Journal of Management Development, 34(8), 1019-1030. https://doi.org/10.1108/JMD-10-2014-0138

Guan, Y., Wen, Y., Chen, S., Liu, H., Si, W., Liu, Y., ... Dong, Z. (2014). When do salary and job level predict career satisfaction and turnover intention among Chinese managers? The role of perceived organizational career management and caree anchor. European Journal of Work and Organizational Psychology, 23(4), 596-607. https://doi.org/10.1080/1359432X.2013.763403

Gubler, M., Biemann, T., Tschopp, C., \& Grote, G. (2015). How career anchors differentiate managerial career trajectories: A sequence analysis perspective. Journal of Career Development, 42(1), 412-430. https://doi.org/10.1177/0894845315572891

Hackman, J.R., \& Oldham, G.R. (1974). The job diagnostic survey: Instrument for the diagnosis of jobs and the evaluation of job redesign projects. New Haven, CT: Yale University.

Hackman, J.R., \& Oldham, G.R. (1975). Development of the job diagnostic survey. Journal of Applied Psychology, 60(2), 159-170. https://doi.org/10.1037/h0076546

Hayward, D., Bungay, V., Wolff, A.C., \& MacDonald, V. (2016). A qualitative study of experienced nurses' voluntary turnover: Learning from their perspectives. Journa of Clinical Nursing, 25(9-10), 1336-1345. https://doi.org/10.1111/jocn.13210

Hudgins, T.A. (2016). Resilience, job satisfaction and anticipated turnover in nurse leaders. Journal of Nursing Management, 24(1), E62-E69. https://doi.org/10. 1111/jonm.12289

Hunt, D. (2014). Does value congruence between nurses and supervisors effect job satisfaction and turnover? Journal of Nursing Management, 22(5), 572-582. https://doi.org/10.1111/jonm.12055

Jiang, J.J., \& Klein, G. (1999). Supervisor support and career anchor impact on the career satisfaction of the entry-level information systems professional. Journal of Management Information Systems, 16(3), 219-240. https://doi.org/10.1080/074 21222.1999.11518262

Jordan, Z. (2009). Magnet recognition and practice development: Two journeys towards practice improvement in health care, Journal of Social Welfare and Management, 165(3), 757-761.

Kaye, B., \& Jordan-Evans, S. (2014). Love 'em or lose 'em: Getting good people to stay. San Francisco, CA: Bernett-Koehler.
Lartey, S., Cummings, G., \& Profetto-McGrath, J. (2014). Interventions that promote retention of experienced registered nurses in health care settings: A systematic retention of experienced registered nurses in health care settings: A systematic
review. Journal of Nursing Management, 22(8), 1027-1041. https://doi.org/ review. Journal of Nur.

Lee, J.A., \& Park, S.H. (2018). Analysis of educational needs for career anchor and career development of nursing students. Journal of the Korea Academia-Industrial cooperation Society, 19(4), 293-300.

Leveck, M.L., \& Jones, C.B. (1996). The nursing practice environment, staff retention and quality of care. Research in Nursing and Health, 19(4), 331-343. https://doi. org/10.1002/(SICI)1098-240X(199608)19:4<331::AID-NUR7>3.0.CO;2-J

Lin, Z., Yu, Z., \& Zhang, L. (2014). Performance outcomes of balanced scorecard application in hospital administration in China. China Economic Review (1043951X), 30(1), 1-15. https://doi.org/10.1016/j.chieco.2014.05.003

Mazurenko, O., Gupte, G., \& Shan, G. (2015). Analyzing US nurse turnover: Are nurses leaving their jobs or the profession itself? Journal of Hospital Administration, 4(4), 48-56. https://doi.org/10.5430/jha.v4n4p48

$\mathrm{Mi}, \mathrm{Y}$. (2016). Factors affecting turnover intention for new graduate nurses in three transition periods for job and work environment satisfaction. Journal of Continuing Education in Nursing, 47(3), 120-131. https://doi.org/10.3928/00220124Education in

Msondo, N.D.P. (2014). The relationship between career anchors and retention factors among women in technical functions within mining company. Master's thesis, University of South Africa, Johannesburg.

Muller, M., Bezuidenhout, M., \& Jooste, K. (2009). Healthcare service management Cape Town: Juta.

Osuji, J., Uzoka, F.M., Aladi, F., \& El-Hussein, M. (2014). Understanding the factors that determine registered nurses' turnover intentions. Research and Theory for Nursing Practice, 28(2), 140-161. https://doi.org/10.1891/1541-6577.28.2.140

Parry, J. (2008). Intention to leave the profession: Antecedents and role in nurse turnover. Journal of Advanced Nursing, 64(2), 157-167. https://doi.org/10.1111/ j.1365-2648.2008.04771.x

Race, T.K., \& Skees, J. (2010). Changing tides: Improving outcomes through mentorship on all levels of nursing. Critical Care Nursing Quarterly, 33(2), 163-176. https:// doi.org/10.1097/CNQ.0b013e3181d91475

Schein, E.H. (1975). Career anchors holds executives to their career paths. Personnel, 52(3), 11-24

Schein, E.H. (1996). Career anchors revisited: Implications for career development in the 21 st century. Academy of Management Executive, 10(4), 80-88. https://doi org/10.5465/ame.1996.3145321

Shahnawaz, M.G., \& Jafri, M.H. (2009). Exploring antecedents of employees turnover in India. Abhigyan, 26(4), 25-40.

Shahzad, K., Hayat, K., Abbas, M., \& Bashir, S. (2011). Antecedents of turnover and absenteeism: Evidence from public sector institutions of Pakistan. Interdisciplinary Journal of Contemporary Research in Business, 2(9), 108-120.

Staggs, V.S., \& Dunton, N. (2012). Hospital and unit characteristics associated with nursing turnover include skill mix but not staffing level: An observational crosssectional study. International Journal of Nursing Studies, 49(9), 1138-1145. https://doi.org/10.1016/j.ijnurstu.2012.03.009

Tiplic, D., Brandmo, C., \& Elstad, E. (2015). Antecedents of Norwegian beginning teachers' turnover intentions. Cambridge Journal of Education, 45(4), 451-474. https://doi.org/10.1080/0305764X.2014.987642

Uruthirapathy, A.A., \& Grant, G. (2015). The influence of job characteristics on IT and non-IT job professional's turnover intentions. Journal of Management Development, 34(6), 715-728. https://doi.org/10.1108/JMD-03-2014-0025

Van Dyk, J., \& Coetzee, M. (2012). Retention factors in relation to organisational commitment in medical and information technology services. SA Journal of Human Resource Management, 10(2), Art. \#433. https://doi.org/10.4102/sajhrm. v10i2.433

Vlastarakos, P.V., \& Nikolopoulos, T.P. (2008). The interdisciplinary model of hospital administration: Do health professionals and managers look at it in the same way? European Journal of Public Health, 18(1), 71-76. https://doi.org/10.1093/eurpub/ $\mathrm{ckm042}$

Wall, T., Clegg, C., \& Jackson, P. (1978). An evaluation of the job characteristics model. Journal of Occupational Psychology, 51(2), 83-196. https://doi.org/10.1111/ Journal of Occupational Psyc

Warmelink, J., Wiegers, T., De Cock, P., Spelten, E., \& Hutton, E.K. (2015). Career plans of primary care midwives in the Netherlands and their intentions to leave the current job. Human Resources for Health, 29(13), 1-10. https://doi.org/10.1186/ s12960-015-0025-3

Weiss, P.J. (2019). Physicians, heal one another: A letter to healthcare administrators. In D.E. McCallister \& T. Hamilton (Eds.), Transforming the heart of practice (pp. 97-100). Cham: Springer.

Wen, Y., \& Liu, L. (2015). Career plateau and turnover intention in Chinese employees: Career anchor as moderator. Social Behavior and Personality, 43(5), 757-766. https://doi.org/10.2224/sbp.2015.43.5.757

Wheeler, A.R., Halbesleben, J.B., \& Harris, K.J. (2012). How job-level HRM effectiveness influences employee intent to turnover and workarounds in hospitals. Journal of Business Research, 65(4), 547-554. https://doi.org/10.1016/j.jbusres.2011.02.020

Yonge, O., Myrick, F., Billay, D., \& Luhanga, O. (2007). Preceptorship and mentorship: Not merely a matter of semantics. International Journal of Nursing Education Scholarship, 4(2), 1-13. https://doi.org/10.2202/1548-923X.1384

Yu, M., \& Kang, K.J. (2016). Factors affecting turnover intention for new graduate nurses in three transition periods for job and work environment satisfaction. Journal of Continuing Education in Nursing, 47(3), 120-131. https://doi. Journal of Continuing Education in
org/10.3928/00220124-20160218-08 